\title{
TEKNOLOGI OPINION MINING UNTUK MENDUKUNG STRATEGIC PLANNING
}

\author{
Dwi Rolliawati*1, ${ }^{\text {Khalid }}{ }^{2}$, Indri Sudanawati Rozas ${ }^{3}$ \\ 1,2,3 Program Studi Sistem Informasi, Fakultas Sains dan Teknologi, UIN Sunan Ampel Surabaya \\ Email: ${ }^{1}$ dwi_roll@uinsby.ac.id, ${ }^{2}$ khalid@uinsby.ac.id, ${ }^{3 i n d r i s r o z a s @ u i n s b y . a c . i d ~}$ \\ *Penulis Korespondensi
}

(Naskah masuk: 23 Januari 2019, diterima untuk diterbitkan: 06 Februari 2020)

\begin{abstract}
Abstrak
Banjir data di era Big Data sudah tidak bisa terelakkan lagi. Termasuk di dalamnya data yang sangat melimpah di media sosial daring. Peluang inilah yang ditangkap sebagai alasan utama pada penelitian ini. Opinion mining sebagai salah satu teknologi dalam mengolah data teks untuk memperoleh arah informasi dari komentar/opini masyarakat. Mengambil obyek penelitian UIN Sunan Ampel Surabaya, penelitian ini bertujuan untuk menganalisis opini masyarakat tentang kampus Islam terbesar di Surabaya. Sehingga bisa menjadi pendukung keputusan bagi pihak manajemen untuk merumuskan perencanaan strategis terwujudnya visi World Class University. Penelitian ini menggunakan 4009 data sampel berbahasa Indonesia yang diambil dari opini masyarakat di media sosial Twitter dalam kurun waktu dua tahun terakhir (2017 - 2018). Dari 4009 data dihasilkan 31837 jenis kata setelah melalui proses stop-word removal. Berdasarkan analisis sentiment menggunakan pendekatan Vader dan Liu yang divisualisasikan melalui grafik K-Means, dihasilkan bahwa opini publik terhadap UIN Sunan Ampel mengarah pada sentimen 'netral' sebesar 97,54\%, sedangkan sentiment positif $=2,16 \%$, dan sentiment negatif $=0,34 \%$. Hasil tersebut membuktikan bahwa Information Capital tentang UIN Sunan Ampel perlu diperkuat menuju nilai "positif". Sehingga diperlukan upaya maksimal untuk membangun innovation and commercially supremacy, perception (public relation) dan scalability strategies supaya internal operation bisa handal untuk ketercapaian visi misi UIN Sunan Ampel Surabaya.
\end{abstract}

Kata Kunci: Big Data, Opinion Mining, World Class University, Twitter, K-Means, Vader, Liu.

\section{OPINION MINING TECHNOLOGY TO SUPPORT STRATEGIC PLANNING}

\begin{abstract}
Data deluge in Big Data era is inevitable, this including a very abundant data in online social media. This phenomenon was chosen as the main background reason in this research. Opinion mining is as one of the technologies in processing text data to obtain information direction from public comments/opinions. Taking the object of research at Sunan Ampel Islamic State University Surabaya, this study aims to analyze public community opinion toward the biggest Islamic campus in Surabaya. Hopefully, it would be beneficial as decisional support for management in formulating strategic planning to manifest the World Class University vision. This study uses 4009 Indonesian language sample data taken from public opinion on Twitter social media in the past two years (2017 - 2018). Out from 4009 data, 31837 types of words are obtained after going through a stop-word removal process. Based on sentiment analysis by Vader and Liu's approach which was visualized by K-Means graphs, the finding was that 97,54\% of public opinion toward Sunan Ampel Islamic State University Surabaya led to a 'neutral' sentiment, while positive $=2,16 \%$ and negative $=0,34 \%$. These results prove that Information Capital about Sunan Ampel UIN needs to be strengthened towards "positive" image. For this reason, maximum effort is needed to build innovation and commercialization of supremacy, perception (public relations) and scalability strategies so that internal operations can be reliable in achieving the vision of Sunan Ampel Islamic State University Surabaya.
\end{abstract}

Keywords: Big Data, Opinion Mining, World Class University, Twitter, K-Means, Support Vector Machine. 


\section{PENDAHULUAN}

Teknologi media sosial telah menjadi mainstream bagi peradaban manusia, dan bukan lagi sesuatu yang baru bagi masyarakat dunia, termasuk di Indonesia. Berdasarkan penelitian yang dilakukan oleh We Are Social yang bekerjasama dengan Hootsuite, diungkapkan bahwa sebesar 130 juta Are Social total populasi Indonesia saat ini mencapai 265,4 juta jiwa, dan setengah dari populasi tersebut (132,7 juta jiwa) merupakan pengguna internet (Hutchison, 2018).

Fakta lainnya menunjukkan bahwa orang Indonesia rata-rata menghabiskan waktu selama 8,85 jam atau setara dengan 8 jam 51 menit untuk berselancar di internet. Adapun rata-rata berkecimpung di media sosial melalui berbagai perangkat hingga 3,38 jam (3 jam 23 menit). Dari berbagai macam media sosial yang ada saat ini, platform yang paling banyak digunakan oleh orang Indonesia, di antaranya YouTube sebesar 43\%, Facebook sebesar 41\%, WhatsApp sebesar 40\%, Instagram sebesar $38 \%$, Line sebesar 33\%, BBM sebesar 28\%, Twitter sebesar 27\%, Google+ sebesar 25\%, FB Messenger sebesar 24\%, LinkedIn sebesar $16 \%$, Skype sebesar 15\%, dan WeChat sebesar $14 \%$ (Hutchison, 2018).

Hal tersebut menunjukkan sebagian orang lebih banyak bersosialisasi di dunia maya daripada dunia nyata. Fungsi awal dari media sosial, yang tadinya hanya untuk mendekatkan dan menjalin silaturahmi antar teman atau keluarga, kini telah berkembang menjadi penyedia dan penyebar informasi, segmen pasar baru bagi dunia bisnis, serta pengembangan jejaring, komunitas, penggiriringan opini dan riset.

Teknologi opinion mining atau sentiment analysis sebagai salah satu dari natural language processing atau studi komputasional yang mengumpulkan, menganalisis, menelusuri opini, sikap dan emosi publik terhadap suatu produk atau entitas tertentu (Medhat, Hassan and Korashy, 2014). Melalui sumber daya media sosial telah banyak dikembangkan penelitian terkait opinion mining, salah satunya adalah Lie Chen, dkk yang memetakan tren riset dan sitasinya tentang market stock dari web media. Hasil riset Lie menunjukkan bahwa sitasi paling tinggi pada riset Twitter mood predicts the stock market dengan besaran 2785 sitasi. Hasil penelitian ini menunjukkan bahwa web media terutama social media terutama Twitter bisa digunakan untuk memprediksi tren suatu entitas ( $\mathrm{Li}$ et al., 2018).
Berbeda dengan Lie, El-Gohary menggali opini stakeholder sebagai alat identifikasi dalam membuat large-scale highway project (Lv and ElGohary, 2016). Sedangkan Thamrin membuat aplikasi matriks rule based SWOT analysis menggunakan teknik sentiment analysis. Metode sentiment analysis digunakan untuk menjaring nilai sentiment dari opini stakeholder suatu perguruan tinggi berdasar pada Standar Nasional Pendidikan Tinggi (Thamrin and Pamungkas, 2017). Melalui teknologi opinion mining tersebut akan diketahui positioning suatu perguruan tinggi menurut persepsi masyarakat. Dengan demikian urgensi dari penelitian ini masuk kategori penting mengingat sumber daya media sosial di Indonesia sangatlah besar dan belum banyak riset yang mengangkat opinion mining sebagai langkah untuk menentukan strategic planning bagi perguruan tinggi. Adapun yang menjadi obyek penelitian adalah UIN Sunan Ampel Surabaya. Hal ini dimaksudkan untuk mengetahui apakah tercapainya visi misi UIN Sunan Ampel Surabaya "menjadi Universitas Islam yang unggul dan kompetitif bertaraf internasional" sudah bisa diprediksi secara tepat dan tidak hanya sebagai wacana saja.

\section{STATE OF THE ART}

\section{A. Literature Review}

\section{Opinion Mining}

Pada beberapa literatur (Pang \& Lee, 2006), (Liu, 2012), dan (Sneka \& Vidhya, 2016), disebutkan bahwa analisis sentimen sama dengan opinion mining, yaitu bidang studi yang menganalisis opini, sentimen, evaluasi, penilaian, sikap, dan emosi orang terhadap entitas seperti produk, layanan, organisasi, individu, masalah, peristiwa, topik, dan berbagai atribut lainnya. Berdasarkan literature ditemukan penyebutan berbagai nama dengan perbedaan definisi yang sangat tipis seperti sentiment analysis, opinion mining, opinion extraction, sentiment mining, subjectivity analysis, affect analysis, emotion analysis, dan review mining. Semua istilah tersebut berada di payung besar sentiment analysis dan opinion mining. Makna opini itu sendiri masih sangat luas. Analisis sentimen dan penambangan opini berfokus pada pendapat yang mengungkapkan atau menyiratkan sentimen positif atau negatif. Analis data pada sentiment menghasilkan tuple berpasangan (Polaritas, Subjektivitas). Tuple Polaritas memiliki nilai $[-1,1]==>$ negative positive. Sentimen Subjectivity memiliki nilai antara 0 sampai 1 , dimana 0 paling objektif dan 1 paling subjektif (Liu, 2012). 


\section{Social Media Analytic (SMA)}

SMA adalah sebuah proses pengumpulan data dari media sosial dan analisanya untuk mendapatkan 'insights' atau informasi berharga untuk suatu tujuan tertentu (Stieglitz et al., 2018). Terdapat 6 langkah dalam social media analytic (Dr. Khan, 2017) yaitu identification, extraction, cleaning, analyzing, visualization dan interpretation yang digambarkan sebagaimana pada Gambar 1 .

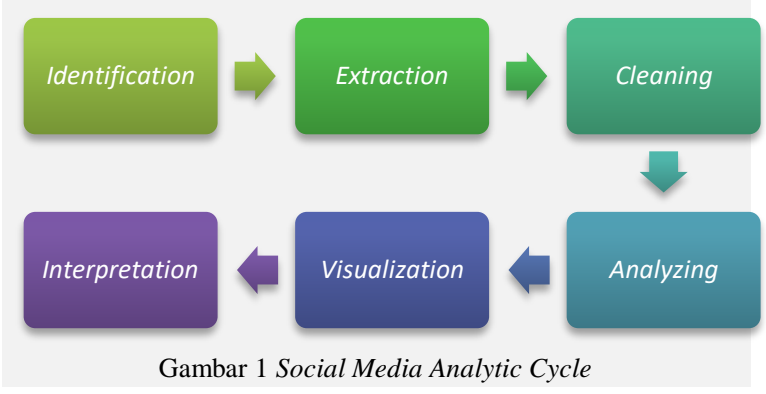
2014):

Tantangan dalam SMA adalah (Stieglitz et al.,

1. Pendek (short in lengths): bahkan terkadang tidak mengandung sebuah kalimat yang utuh menurut tata bahasa (grammar).

2. Noise: data media sosial penuh dengan noise seperti typos (salah ketik), encoding yang tidak jamak, slang, dsb.

3. Temporal: informasi yang sedang trending biasanya hanya sesaat, sehingga SMA diharapkan dilakukan dengan cepat menggunakan modelmodel/teknik-teknik analisa data yang efisien.

4. High-dimensional: data di media sosial (teks, gambar, video, suara, dsb) adalah data tidak terstruktur berdimensi tinggi.

5. Fine-grained: data di media sosial berasal dari banyak user yang masing-masingnya bisa jadi membahas beberapa topik yang berbeda. Sehingga komunitas (kelompok), topik, maupun klasifikasi yang ada menjadi besar (fine-grained).

6. Large in volume \& high velocity: data yang sangat besar dan bertambah besar dengan cepat.

7. A lot of external information: informasi terkadang lebih banyak terkandung dari luar (eksternal) seperti url website, video, atau hal lain yang dibagikan oleh pengguna media sosial.

\section{Pendekatan Vader dan Liu}

Metode VADER merupakan singkatan dari Valence Aware Dictionary for sEntiment Reasoning yang menggunakan simple rule based model. Dari riset yang dilakukan, metode VADER menunjukkan tingkat akurasi yang tinggi untuk sentiment menggunakan data tweet, yaitu sebesar 0,96 jika dibandingkan dengan 11 metode lainnya sebagaimana Gambar 2.
Sedangkan metode Liu yang digagas oleh Bing Liu menggunakan pendekatan supervised pattern learning untuk mengekstraksi fitur objek dan mengidentifikasi orientasi suatu opini. Untuk mengidentifikasi orientasi opini, Liu menggunakan pendekatan berbasis leksikon. Pendekatan leksikon pada dasarnya menggunakan kata-kata dan frasa dalam sebuah kalimat untuk menentukan sentiment dari sebuah opini. Pendekatan berbasis leksikon memiliki langkah: identifikasi kata-kata opini, mencari kata-kata negasi, dan terakhir but-clauses (Mishra, 2012).

\begin{tabular}{|c|c|c|c|c|}
\hline & \multicolumn{4}{|c|}{$\begin{array}{l}\text { 3-Class Classification Accuracy (F1 scores) } \\
\text { Test Sets }\end{array}$} \\
\hline & Tweets & Movie & Amazon & NYT \\
\hline VADER & 0.96 & 0.61 & 0.63 & 0.55 \\
\hline NB (tweets) & 0.84 & 0.53 & 0.53 & 0.42 \\
\hline ME (tweets) & 0.83 & 0.56 & 0.58 & 0.45 \\
\hline SVM-C (tweets) & 0.83 & 0.56 & 0.55 & 0.46 \\
\hline SVM-R (tweets) & 0.65 & 0.49 & 0.51 & 0.46 \\
\hline NB (movie) & 0.56 & 0.75 & 0.49 & 0.44 \\
\hline ME (movie) & 0.56 & 0.75 & 0.51 & 0.45 \\
\hline NB (amazon) & 0.69 & 0.55 & 0.61 & 0.48 \\
\hline ME (amazon) & 0.67 & 0.55 & 0.60 & 0.43 \\
\hline SVM-C (amazon) & 0.64 & 0.55 & 0.58 & 0.42 \\
\hline SVM-R (amazon) & 0.54 & 0.49 & 0.48 & 0.44 \\
\hline $\mathrm{NB}(\mathrm{nyt})$ & 0.59 & 0.56 & 0.51 & 0.49 \\
\hline ME (nyt) & 0.58 & 0.55 & 0.51 & 0.50 \\
\hline
\end{tabular}

Gambar 2 Perbandingan Akurasi Metode VADER (Hutto and Gilbert, 2014)

\section{Strategic Planning}

Perencanaan strategis (strategic planning) adalah sebuah cara organisasi dalam mempersiapkan perubahan dan memberikan arahan serta mengkoordinasikan kegiatannya secara internal untuk mencapai tujuan organisasi yang ditetapkan (Ritson, 2011). Strategi sendiri dikategorikan ke dalam beberapa jenis. Ada planned strategy, emergent strategy, opportunistic strategy, dan imposed strategy. Strategic plan merupakan bentuk dari planned strategy yang ketika diturunkan ke dalam deliberate strategy diharapkan dapat diimplementasikan atau realized strategy (Ritson, 2011). Ritson menggambarkan hubungan antar jenis strategi dalam Gambar 3.

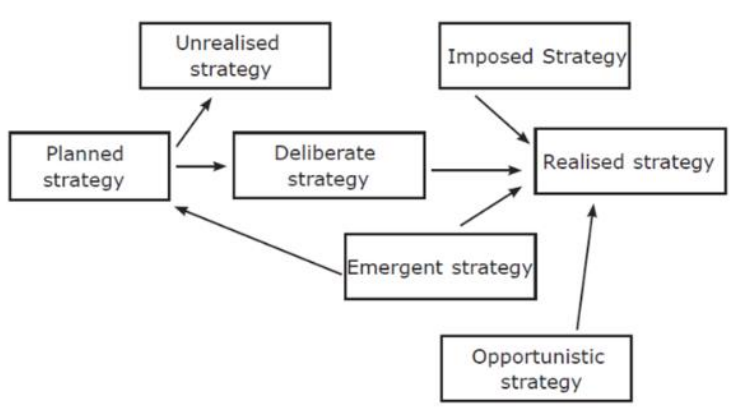

Gambar 3 Relasi Antar Jenis Strategi

\section{B. Previous Research}

Penelitian tentang opinion mining telah banyak dilakukan dan menjadi trend di era big data saat ini. "Apa yang orang lain pikirkan" selalu 
menjadi bagian informasi penting bagi sebagian besar dari kita selama proses pengambilan keputusan (Pang and Lee, 2006). Relevansi penelitian terdahulu dengan penelitian ini digambarkan keterkaitannya dalam Gambar 4.

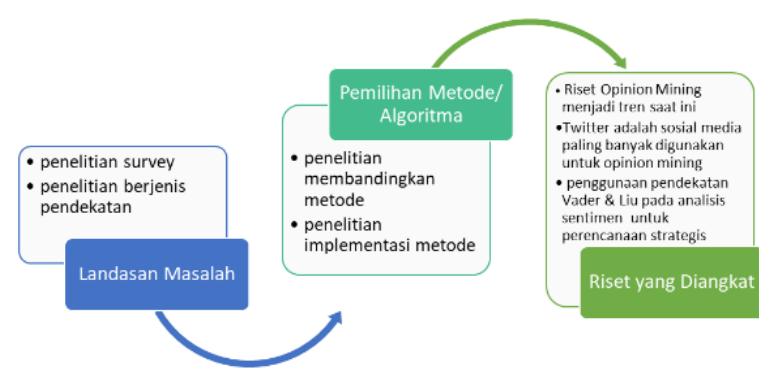

Gambar 4 Keterkaitan Penelitian Terdahulu

Beberapa penelitian yang menjadi tolok ukur landasan masalah dalam penelitian ini sebagaimana paparan berikut. Penelitian oleh Li, dkk yang memetakan 2785 tren riset dan sitasinya tentang stok market dan web media Twitter (Li et al., 2018). Survei dari penelitian Hussein membahas faktor penting dan efek tantangan dalam analisis sentimen dari 47 makalah yang diteliti. (Singh and Husain, 2014).

Adapun terkait metode pengolahan data, Tahun 2014 Medhat melakukan survey tentang opinion mining dan sentiment analysis untuk menentukan tren riset dan algoritma yang digunakan. Dari hasil survei tersebut dihasilkan bahwa Nä̈ve Bayes dan Support Vector Machine (SVM) adalah metode yang paling baik untuk diimplementasikan dalam sentiment analysis atau opinion mining dan sentiment classification (Medhat, Hassan and Korashy, 2014). Riset yang dilakukan McCoy, dkk untuk memeriksa dan memberi peringkat dari 264 universitas AS yang diekstrak dari keanggotaan dan daftar NCAA Divisi I dan diterbitkan dalam Berita AS menunjukkan bahwa Times Higher Education (THE), Peringkat Akademik Universitas Dunia (ARWU), dan Money Magazine menggunakan peringkat reputasi yang disesuaikan dan dibandingkan dengan skor keterlibatan Twitter di perguruan tinggi (McCoy, Nelson and Weigle, 2017).

Samir menggunakan pendekatan semantik untuk menemukan sikap pengguna dan wawasan bisnis dari media social Twitter dalam bahasa Arab, baik standar maupun dialek. Dalam penelitian tersebut dibuat pula versi pertama dari Sentiment Ontology (ASO) yang berisi kata-kata berbeda yang mengungkapkan perasaan dan seberapa kuat katakata mengungkapkan perasaan (Tartir and AbdulNabi, 2017). Janssen, dkk membuat studi kasus untuk membuktikan hipotesis bahwa sentimen Twitter dapat secara potensial mendukung sistem peringkat universitas dengan menganalisis pernyataan yang diposting dan pendapat siswa dan guru dalam konteks lembaga pendidikan tinggi (Janssen et al., 2015). Berdasarkan paparan riset sebelumnya terlihat nyata bahwa social media, salah satunya Twitter adalah sumber daya yang paling banyak digunakan untuk riset opinion mining.

Adapun pijakan dalam pemilihan metode yang terbaik dalam penelitian ini adalah berdasarkan riset-riset berikut ini. Analisis opinion mining terhadap suatu produk di amazon.com dengan 3 metode classifier yaitu naïve bayes, SVM dan decision tree. Dari ketiga metode yang diujikan diperoleh tingkat akurasi yang tinggi sebesar 81,75\% terhadap penggunaan metode SVM dibandingkan dengan metode lainnya (Singla, Randhawa and Jain, 2017). Hal serupa dilakukan oleh (Devika, Sunitha and Ganesh, 2016) yang membandingkan metodemetode penggalian data dengan menggunakan algoritma Support Vectore Machine, N Gram, Naïve Bayes, KNN, ME Classifier, Feature Selection, dan Multilingual SA. Riset opinion mining (Science and Engineering, 2016) yang membandingkan algoritma Support vector machine- nearest neighbour, K-means clustering dan SOM (Artificial Neural network). Masih tentang sentiment analisis/opinion mining, dimana data opini dari amazon.com digunakan untuk kategorisasi suatu produk menggunakan naïve bayes classifier, random forest dan SVM (support vector machine) (Fang and Zhan, 2015).

Putranti mengimplementasi sentiment public dalam Bahasa Indonesia untuk mengetahui positioning telkomsel, indosat, iklan dan operator seluler lainnya (Putranti and Winarko, 2014) dan hal serupa dilakukan oleh Haddi (Haddi, Liu and Shi, 2013). Riset opinion mining oleh Rozi,dkk digunakan untuk menganalisis opini publik pada perguruan tinggi Polinema, Malang (Rozi, Pramono and Dahlan, 2012). Sisi lain opinion mining adalah untuk membandingkan produk dari hasil review konsumen untuk menentukan SWOT suatu produk dalam mendukung kesuksesan marketing (Auinger and Fischer, 2008).

Berdasarkan semua paparan riset sebelumnya, state of the art dalam penelitian ini adalah mengangkat opinion mining untuk mendukung perencanaan strategis suatu Lembaga Perguruan Tinggi dengan menggunakan pendekatan Vader dan Liu yang divisualisasikan dalam grafik heatmap berdasarkan metode K-Means. 


\section{METODOLOGI PENELITIAN}

Secara umum, metodologi yang digunakan dalam menyelesaikan penelitian sebagaimana digambarkan pada Gambar 4.

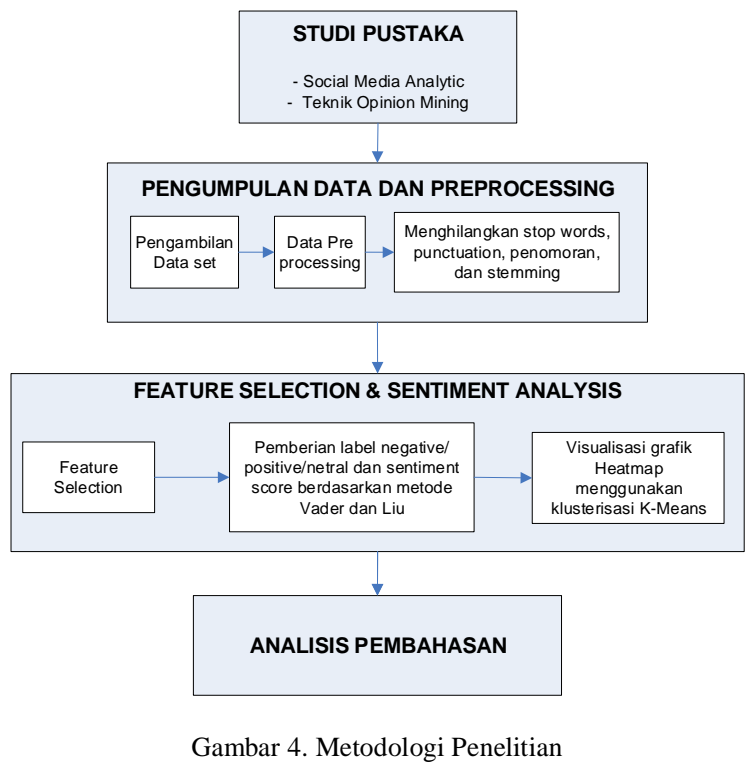

Sebagaimana diagram alir pada Gambar 4, ada tiga langkah utama yang dilakukan dalam penelitian ini. Yang pertama yaitu studi pustaka, yang hasilnya telah dipaparkan pada bagian 2 (State Of The Art). Langkah kedua yaitu pengumpulan data dan preprocessing. Yang dilakukan pada langkah ini yaitu teknik pengumpulan data melalui crawling data Twitter secara daring dengan menggunakan API Key Twitter. Data yang diambil adalah 2 tahun terakhir yaitu 2017 dan 2018 dengan keyword yang ditentukan.

Langkah ketiga adalah feature selection dan sentiment analysis. Tahapan ini memetakan data tweet hasil crawling dengan memberikan label pada suatu kalimat tweet berdasarkan ukuran polaritas dan subyektifitasnya menggunakan pendekatan Vader \& Liu. Untuk memudahkan dalam melakukan analisis dan menghilangkan data yang mirip/redundan maka dilakukan klasterisasi menggunakan metode $\mathrm{K}$ Means. Hasil klasterisasi dokumen direpresentasikan dalam bentuk grafik heatmap. Setelah semua dilaksanakan barulah kemudian didapatkan hasil dan dilakukan pembahasan.

Langkah keempat yaitu analisis dan pembahasan, pada tahap ini dilakukan analisis hasil penelitian dalam mendukung perencanaan strategis. Perencanaan strategis yang dimaksud adalah perencanaan strategis IT.

\subsection{Pengumpulan Data dan Pre-processing}

Sebagimana telah disebutkan sebelumnya, data yang di-crawling adalah 2 tahun terakhir (2017 dan 2018) dengan menggunakan keyword sebagai berikut:

1. "UINSA",

2. "UINSBY"

3. "Sunan Ampel"

4. "UIN Sunan Ampel"

5. "UIN Sunan Ampel Surabaya"

Setelah di-crawling, diperoleh data mentah sebanyak 4009 tweet. Dan setelah dilakukan preprocessing, dari 4009 data tweet menghasilkan data token sebanyak 58937 kata dengan total tipe 10100 kata. Dari data 4009 tweet (58937 kata) menjadi 31837 kata ketika proses stop-word removal.

Untuk melihat detil frekuensi dari kata hasil crawling disimpan dalam bentuk tabulasi. Tabel 1 menampilkan frekuensi dari 20 kata teratas (dari 4009) yang muncul berdasarkan data opini publik tentang UIN Sunan Ampel Surabaya.

Tabel 1. Frekuensi Kata dari Data Tweet

\begin{tabular}{clc}
\hline No & Word & Word Count \\
\hline 1 & uinsa & 3325 \\
2 & surabaya & 1380 \\
3 & uin & 1317 \\
4 & sunan & 1298 \\
5 & ampel & 1289 \\
6 & sunan ampel & 1286 \\
7 & uin sunan & 1236 \\
8 & ampel surabaya & 747 \\
9 & info & 510 \\
10 & instagram & 429 \\
11 & mahasiswa & 429 \\
12 & uinsa surabaya & 392 \\
13 & indonesia & 315 \\
14 & nasional & 293 \\
15 & ikuti & 276 \\
16 & auditorium & 257 \\
17 & kampus & 237 \\
18 & center & 232 \\
19 & sport & 229 \\
20 & rektor & 224 \\
\hline & &
\end{tabular}

Jika Tabel 1 memberikan informasi rinci frekuensi kata, maka word-cloud memberikan model visual yang menggambarkan secara global apa saja kata yang paling banyak ditemukan. Kata yang frekuensinya lebih banyak atau paling sering muncul digambarkan dengan font yang lebih besar dibandingkan yang frekuensinya lebih sedikit. Wordcloud tabel di atas terdapat pada Gambar 5 .

\subsection{Feature Selection dan Sentiment Analysis}

Tahapan ini memetakan data 4009 data tweet dengan memberikan label pada suatu kalimat 
tweet bersadarkan ukuran polaritas dan subyektifitasnya menggunakan pendekatan dari Vader dan Liu ('Orange3 Text Mining Documentation', 2018). Vader memetakan opini publik dalam 3 kategori yaitu sentiment positif, sentiment negative dan netral. Nilai compound pada metode Vader ini adalah hasil campuran/gabungan atau bisa juga dikatakan sebagai rata-rata. Sedangkan metode Li hanya memetakan opini dalam 2 kluster yaitu positif dan negative. Secara detail, tahapan klusterisasi positif, negatif dan netral diilustrasikan pada Gambar 6.

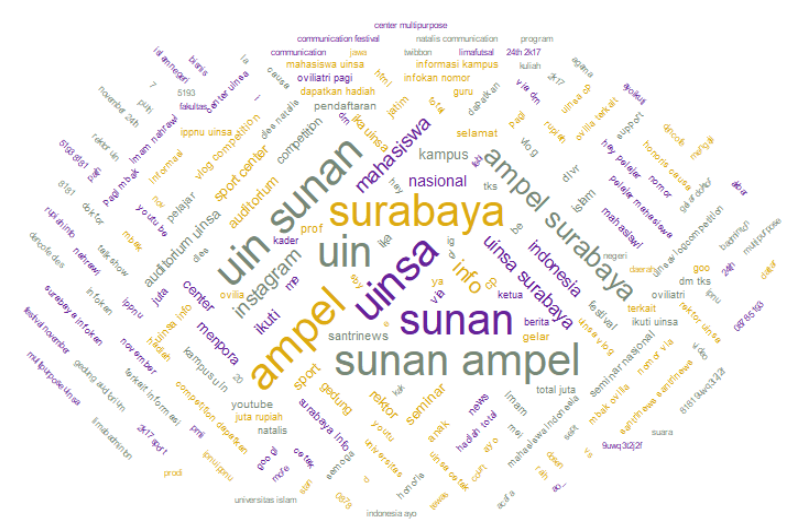

Gambar 5. Word-cloud

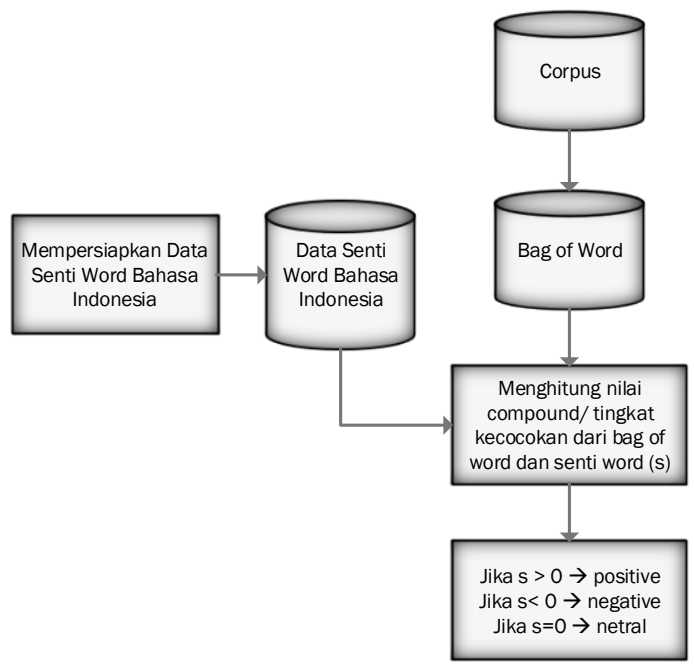

Gambar 6. Tahapan Klusterisasi Opini

Berdasarkan tahapan metode Vader sebagaimana Gambar 6, dihasilkan nilai sentimen pada Tabel 2. Jika dilihat dari 50 data corpus ( $\mathrm{N}=4009)$ yang ditampilkan pada Tabel 2, sebagian besar data tweet menghasilkan nilai sentimen absolut netral yaitu sama dengan " 1 ". Walaupun ada beberapa yang bernilai netral positif sebagaimana pada data corpus ke-15 yang memiliki nilai positif sebesar 0,266 dan netral $=0,734$.

Hasil sentiment pada Tabel 2 menunjukkan bahwa sentiment positif $=2,16 \%$, sentiment negatif $=$ $0,34 \%$ dan sentiment netral $=97,54 \%$. Hasil Tabel 2 masih ditemui beberapa data yang sama/redundan sehingga 4009 data tweet yang sama di-merger tingkat kedekatan dokumennya menjadi 23 kluster dengan menggunakan algoritma K-Means. Hasil dari olahan K-Means divisualisasikan dalam bentuk grafik HeatMap seperti Gambar 7.

Tabel 2. Hasil Sentimen Analysis

\begin{tabular}{|c|c|c|c|c|c|}
\hline No.id & Content & pos & neg & neu & compound \\
\hline 1 & Psikolog Anak U & 0,0000 & 0,0000 & 1,0000 & 0,0000 \\
\hline 2 & Psikolog Anak U & 0,0000 & 0,0000 & 1,0000 & 0,0000 \\
\hline 3 & Psikolog Anak U & 0,0000 & 0,0000 & 1,0000 & 0,0000 \\
\hline 4 & Psikolog Anak U & 0,0000 & 0,0000 & 1,0000 & 0,0000 \\
\hline 5 & http:// TRIBUNS & 0,0000 & 0,0000 & 1,0000 & 0,0000 \\
\hline 6 & Psikolog Anak U & 0,0000 & 0,0000 & 1,0000 & 0,0000 \\
\hline 7 & Psikolog Anak U & 0,0000 & 0,0000 & 1,0000 & 0,0000 \\
\hline 8 & \#SURABAYA - ] & 0,0000 & 0,0000 & 1,0000 & 0,0000 \\
\hline 9 & \#BOJONEGOR( & 0,0000 & 0,0000 & 1,0000 & 0,0000 \\
\hline 10 & Psikolog Anak U & 0,0000 & 0,0000 & 1,0000 & 0,0000 \\
\hline 11 & Psikolog Anak U & 0,0000 & 0,0000 & 1,0000 & 0,0000 \\
\hline 12 & \#MAGETAN RA & 0,0000 & 0,0000 & 1,0000 & 0,0000 \\
\hline 13 & Psikolog Anak U & 0,0000 & 0,0000 & 1,0000 & 0,0000 \\
\hline 14 & Psikolog Anak U & 0,0000 & 0,0000 & 1,0000 & 0,0000 \\
\hline 15 & Wonderful 2016 & 0,2660 & 0,0000 & 0,7340 & 0,6140 \\
\hline 16 & Pementasan Seni & 0,1110 & 0,0000 & 0,8890 & 0,2500 \\
\hline 17 & Pementasan Seni & 0,1110 & 0,0000 & 0,8890 & 0,2500 \\
\hline 18 & [CALL FOR PAI & 0,0000 & 0,0000 & 1,0000 & 0,0000 \\
\hline 19 & \#Repost @urban & 0,0000 & 0,0000 & 1,0000 & 0,0000 \\
\hline 20 & Last Meeting Wi & 0,0000 & 0,0000 & 1,0000 & 0,0000 \\
\hline 21 & Sambang Kader ${ }^{*}$ & 0,0000 & 0,0000 & 1,0000 & 0,0000 \\
\hline 22 & Saya suka video ' & 0,0000 & 0,0000 & 1,0000 & 0,0000 \\
\hline 23 & Pementasan Seni & 0,1110 & 0,0000 & 0,8990 & 0,2500 \\
\hline 24 & 'yg gaada barisan & 0,0000 & 0,0000 & 1,0000 & 0,0000 \\
\hline 25 & [CONFERENCE & 0,0000 & 0,0000 & 1,0000 & 0,0000 \\
\hline 26 & [CONFERENCE & 0,0000 & 0,0000 & 1,0000 & 0,0000 \\
\hline 27 & [CONFERENCE & 0,0000 & 0,0000 & 1,0000 & 0,0000 \\
\hline 28 & Pementasan Seni & 0,1050 & 0,0000 & 0,8950 & 0,2500 \\
\hline 29 & Pementasan Seni & 0,1110 & 0,0000 & 0,8990 & 0,2500 \\
\hline 30 & Alhamdulillah se & 0,0000 & 0,0000 & 1,0000 & 0,0000 \\
\hline 31 & Owh kmu kuliah & 0,0000 & 0,0000 & 1,0000 & 0,0000 \\
\hline 32 & At UIN Sunan Ar & 0,0000 & 0,0000 & 1,0000 & 0,0000 \\
\hline 33 & Banyak cara untu & 0,0000 & 0,0000 & 1,0000 & 0,0000 \\
\hline 34 & UINSA di petang & 0,0000 & 0,0000 & 1,0000 & 0,0000 \\
\hline 35 & uinsa mbaak hehs & 0,0000 & 0,0000 & 1,0000 & 0,0000 \\
\hline 36 & The English Ren: & 0,0000 & 0,0000 & 1,0000 & 0,0000 \\
\hline 37 & HIMASI UNTAC & 0,1850 & 0,0790 & 0,7360 & 0,4329 \\
\hline 38 & Pengurus Luban§̨ & 0,8190 & 0,0000 & 0,7810 & 0,4215 \\
\hline 39 & \#nemu Foto 4tah & 0,0000 & 0,0000 & 1,0000 & 0,0000 \\
\hline 40 & Pertemuan +-51 & 0,0000 & 0,0000 & 1,0000 & 0,0000 \\
\hline 41 & Pertemuan +-51 & 0,0000 & 0,0000 & 1,0000 & 0,0000 \\
\hline 42 & \#pathdaily (at UI & 0,0000 & 0,0000 & 1,0000 & 0,0000 \\
\hline 43 & Just posted a phc & 0,0000 & 0,0000 & 1,0000 & 0,0000 \\
\hline 44 & [GREETINGS] \# & 0,0000 & 0,0000 & 1,0000 & 0,0000 \\
\hline 45 & [GREETINGS] \# & 0,0000 & 0,0000 & 1,0000 & 0,0000 \\
\hline 46 & I liked a @YouTi & 0,2590 & 0,0000 & 0,7410 & 0,4215 \\
\hline 47 & Joss Gandoss UI & 0,0000 & 0,0000 & 1,0000 & 0,0000 \\
\hline 48 & Anak Pedagang $f$ & 0,0000 & 0,0000 & 1,0000 & 0,0000 \\
\hline 49 & Surabaya, Univer & 0,0000 & 0,0000 & 1,0000 & 0,0000 \\
\hline \multirow[t]{3}{*}{50} & ANAK PEDAG $A$ & 0,0000 & 0,0000 & 1,0000 & 0,0000 \\
\hline & AVERAGE & 0,0216 & 0,0034 & 0,9754 & 0,0434 \\
\hline & AVERAGE (\%) & $2,16 \%$ & $0,34 \%$ & $97,54 \%$ & $4,34 \%$ \\
\hline
\end{tabular}

Berdasarkan visualisasi tersebut, terlihat jelas bahwa semua data twet yang diambil dari Twitter berdasarkan kata kunci UINSA, UINSBY, UIN Sunan Ampel, Sunan Ampel berisi opini/komentar yang bersifat netral. Gradasi warna dari setiap kolom nilai pos (positif), neg (negative) dan neu (netral) memiliki arti semakin berwarna gelap maka nilainya mendekati satu (1.0), semakin 
berwarna muda maka nilainya semakin mendekat nol (0.0). Dan jika menggunakan metode Liu, yang hanya memiliki penilaian sentiment bernilai positif dan negative saja, grafik HeatMap akan terlihat sebagaimana Gambar 8.

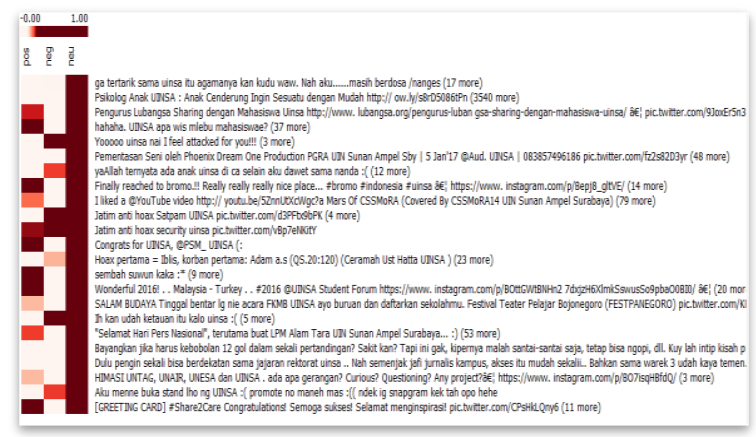

Gambar 7. Grafik HeatMap dari hasil klusterisasi menggunakan K-Means(Lee and Park, 2012)

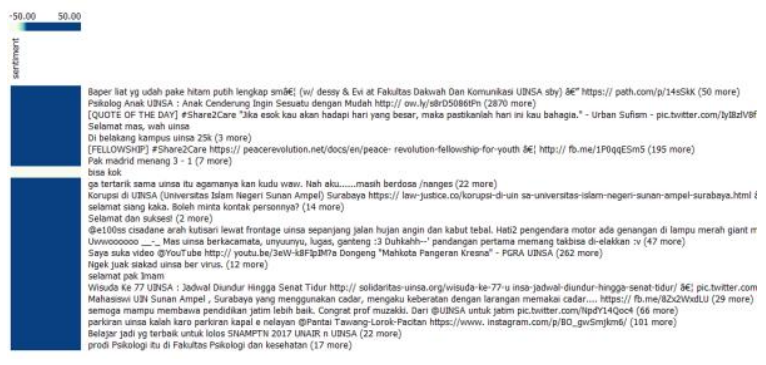

Gambar 8. Grafik HeatMap Metode Liu

Dengan nilai sentiment negatif $=-50$ dan nilai sentiment positif $=50$, hal ini menunjukan bahwa nilai sentiment mengarah pada netral dengan adanya bobot yang sama antara positif dan negatif.

\section{HASIL DAN PEMBAHASAN}

Strategic planning bukanlah sebuah proses yang sederhana, namun berupa fase kompleks dari manajemen strategis yang tergantung pada berbagai informasi terkait organisasi. Dan balanced scorecard memberikan konsep yang menyeluruh untuk kerangka berfikir menuju strategic planning (Stefanovska and Soklevski, 2014) Balanced scorecard memiliki empat perspektif: finance, costumers, internal processes, learning and growth.

Peta strategi (Strategy map) adalah alat sederhana yang mudah digunakan untuk untuk menerjemahkan strategi dari visi dan misi organisasi ke dalam strategic plan. Dengan balanced scorecard, pembuatan strategy map akan lebih mudah dan menyeluruh (Hafnika et al., 2016).

Gambar 9 di bawah ini adalah model dasar dari strategy map berdasarkan balanced scorecard.

Walaupun model pada Gambar 9 merupakan model strategic plan secara umum, namun perguruan tinggi juga selayaknya mengadopsinya, karena berdasarkan Karen E. Hinton dari Society for College and University Planning (2012) dinyatakan bahwa sebagian lembaga pendidikan tinggi di Amerika Serikat menyusun masterplan TI dalam rangka memenuhi kebutuhan strategic plan institusi. Hal ini menunjukkan bahwa di berbagai negara maju, IT sudah dipandang sebagai bagian dari strategic plan untuk kesuksesan perguruan tinggi (Hinton, 2012).

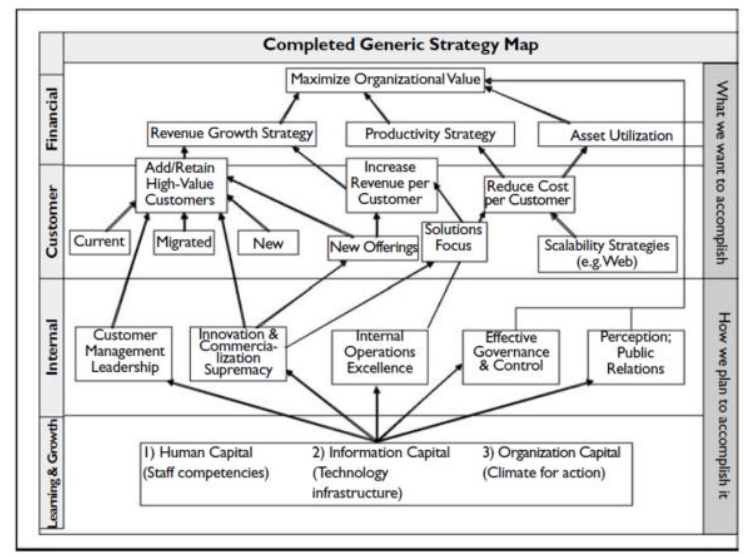

Gambar 9 Peta Strategi

Jika dilihat pada Gambar 9, dua layer paling bawah mengilustrasikan "how we plan to accomplish it", dan dua layer berikutnya adalah "what we want to accomplish it". Untuk mencapai "how we plan" dari sisi IT yaitu melalui Information Capital. Information capital yang didukung oleh infrastruktur teknologi sebagai salah satu elemen yang akan mendukung keberhasilan internal operation, dimana pada akhirnya akan memaksimalkan organizational value (Armitage and Scholey, 2006).

Information capital berelasi dengan 5 bagian yaitu : (1) customer management relationship, (2) innovation and commercially supremacy, (3) internal operation excellence, (4) effective governance and control, dan (5) perception (public relation).

Teknologi opinion mining yang diusung pada penelitian ini adalah untuk mendukung strategic planning pada tahap "how we plan". Hasil opinion mining yang telah dilakukan berkaitan erat dengan poin innovation and commercially supremacy dan perception (public relation) serta mendukung scalability strategies sehingga memaksimalisasi ketercapaian organization value.

UIN Sunan Ampel Surabaya sebagai obyek penelitian memiliki visi "menjadi Universitas Islam yang unggul, dan kompetitif bertaraf internasional". Citacita menjadi World Class University (WCU) Untuk mendukung tercapainya visi tersebut perlu dilihat positioning dari universitas tersebut, salah satunya adalah melalui webometric. Webometric merilis 
kriteria perangkingan versi 2018.2.1.3. Dalam laman web webometric, metodologi kriteria yang digunakan untuk menilai perankingan web suatu universitas adalah presence/web visibility, impact, openness dan excelence (Webometric, 2018)

Gambar 10 menunjukan hasil pencarian melalui mesin pencari daring bahwa posisi UIN Sunan Ampel menurut webometric adalah rangking 4731 dunia, rangking 1788 di Asia, rangking 177 di Asia Tenggara dan rangking 62 di Indonesia (data diambil per 1 November 2018).

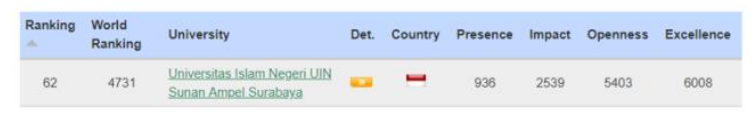

Gambar 10. Posisi UIN Sunan Ampel

Lee menyebutkan bahwa Universitas akan semakin terlihat dari kehadiran/visibilitas dan jejak di Web sebagai pusat reputasi dan kedudukan internasionalnya (Lee and Park, 2012). Dalam konteks ini, web akademik berkembang menjadi lebih dari sekedar wahana untuk mengkomunikasikan prestasi ilmiah dan budaya; konten informasi dipandang sebagai cerminan dari keseluruhan organisasi dan kinerja universitas. Adapun jika dilihat dari sisi "how we plan" dalam strategic planning, khususnya dalam membangun poin innovation and commercially supremacy dan perception (public relation) melalui penambangan opini/persepsi di Twitter, UIN Sunan Ampel terlihat jelas kurang memberdayakan media social sebagai salah satu media teknologi untuk menunjukkan reputasi dan kedudukannya. Jika dilihat kembali hasil analisis data Twitter melalui word-cloud (Gambar 5), tidak ada satupun informasi yang memuat publikasi ilmiah, mahasiswa internasional, bahkan kata internasional saja belum ada dalam persepsi masyarakat. Yang terlihat jelas selain nama kampus adalah "mahasiswa", "nasional", "menpora", "auditorium", "sport center" dan "Instagram". Kriteria tentang sarana prasarana (asset uitilization) baru 2 saja yang muncul yaitu auditorium dan sport center. Untuk itu, UIN Sunan Ampel perlu memaksimalkan informasi di media sosial, paling tidak memuat informasi yang berhubungan dengan kriteria-kriteria WCU.

Dari segi pengambilan data set selama 2 tahun terakhir, hanya didapatkan 4009 data konten tentang UIN Sunan Ampel. Padahal, setiap 5 menit, orang Indonesia berinteraksi dengan internet terutama media sosial (Hutchison, 2018). Hal ini menunjukkan bahwa UIN Sunan Ampel kurang memberikan informasi, sehingga follower yang mengikuti informasi dan menyebarkan informasi tentang UIN Sunan Ampel perlu dikembangkan atau ditambah volumenya. Sebuah penelitian telah merilis indikator University Twitter Engagement untuk merangking institusi berdasarkan pengikut Twitter di suatu institusi. Banyaknya follower di suatu institusi ternyata erat korelasinya dengan reputasi institusi tersebut (Janssen et al., 2015).

Hasil analisis sentimen dari 2 metode: Vader dan Liu menunjukkan bahwa konten opini yang memuat UIN Sunan Ampel, belum ada yang bernilai kuat positif. Sebagian besar bernilai netral, yang artinya opini/persepsi publik terhadap UINSBY dinilai biasabiasa saja. Sehingga, UIN Sunan Ampel perlu strategi untuk membangun innovation and commercially supremacy serta perception (public relation) menjadi lebih kuat nilai positifnya. Gambar 11 menampilkan perbandingan hasil sentimen dari 2 metode yaitu Vader dan Liu. Metode Vader menghasilkan sentiment positif $=2,16 \%$, sentiment negatif $=0,34 \%$ dan sentiment netral $=97,54 \%$. Metode Liu menghasilkan nilai sentiment negatif $=-50$ dan nilai sentiment positif $=50$, yang berarti "netral". Sehingga dapat disimpulkan bahwa dengan menggunakan metode Liu maupun Vader memiliki nilai akhir yang sama, yaitu sentimen yang bersifat "netral" mendominasi dari 4009 data tweet tentang UIN Sunan Ampel.

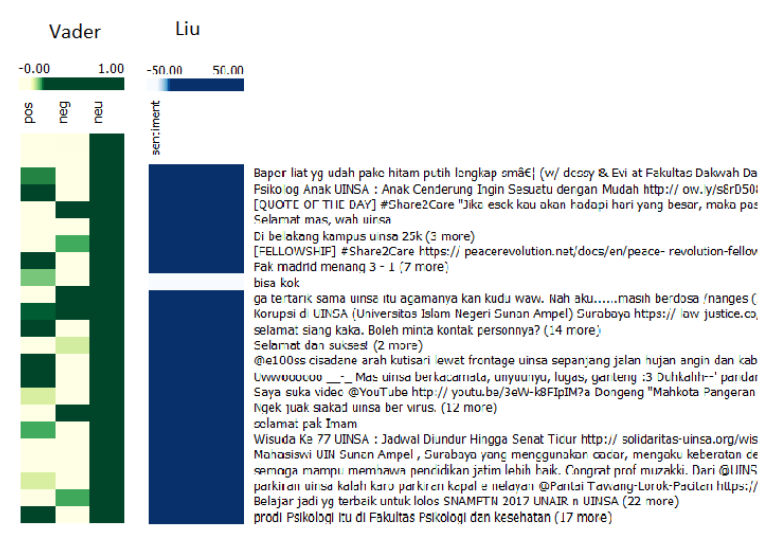

Gambar 11. Perbandingan metode Vader dan Liu

Berdasarkan hasil opinion mining dari Gambar 11, untuk mendukung "how we plan" strategic planning menuju WCU yang merupakan visi misi UIN Sunan Ampel maka perlu dilakukan penguatan Information Capital sebagai berikut:

1. Membangun innovation and commercially supremacy salah satunya dengan memaksimalkan dan memberdayakan sosial media untuk memperkuat positioning di masyarakat melalui peningkatan jumlah follower.

2. Menguatkan perception (public relation) dengan meningkatkan fungsi media sosial sebagai sarana publikasi yang berkaitan dengan kriteria WCU. 
Misal publikasi ilmiah, komunitas keilmuan, diskusi dosen untuk peningkatan akademik, pelayanan pengabdian masyarakat secara daring, dan lain sebagainya.

3. Mempertimbangkan kriteria University Twitter Engagement sebagai sarana untuk meningkatkan visibilitas, reputasi dan jejak di dunia maya sebagai bentuk dari innovation and commercially supremacy.

4. Meningkatkan scalability strategies melalui maksimalisasi fungsi website UIN Sunan Ampel.

Terlepas dari Information Capital, UIN Sunan Ampel juga perlu mempertimbangkan Human Capital dan Organizational Capital untuk men-support Information Capital yang handal dan berdaya guna.

\section{SIMPULAN}

Penelitian ini mengambil data opini/persepsi masyarakat tentang UIN Sunan Ampel sebanyak 4009 data tweet. Analisis menggunakan metode Vader menghasilkan sentiment positif $=2,16 \%$, sentiment negatif $=0,34 \%$ dan sentiment netral $=$ 97,54\%. Sedangkan metode Liu menghasilkan nilai sentiment negatif $=-50$ dan nilai sentiment positif $=$ 50 , yang berarti “netral”. Sehingga dapat disimpulkan bahwa hasil analisis menggunakan metode Liu maupun Vader memiliki nilai akhir yang sama, yaitu sentimen yang bersifat "netral".

Hasil opinion mining tersebut menjadi pijakan dalam mendukung strategic planning. Strategic planning yang dimaksud adalah unsur Information Capital yang didukung oleh infrastruktur teknologi dengan melihat positioning kampus di sosial media. Nilai sentimen persepsi masyarakat yang "netral" membuktikan bahwa Information Capital tentang UIN Sunan Ampel perlu diperkuat menuju nilai “positif”. Sehingga diperlukan upaya maksimal untuk membangun innovation and commercially supremacy, perception (public relation) dan scalability strategies supaya internal operation bisa handal. Penelitian ini masih jauh dari sempurna, kedepan, untuk merancang dan menghasilkan masterplan IT atau strategic plan pada tahap "how we plan" masih diperlukan riset lanjutan yang membahas tentang customer management relationship, internal operation excellence, dan effective governance and control untuk mendukung Information Capital dari UIN Sunan Ampel Surabaya.

\section{DAFTAR PUSTAKA}

ARMITAGE, H. M. and SCHOLEY, C. (2006) Management Accounting Guideline, Using Strategy Maps to Drive Performance. Available at:
http://www.cimaglobal.com/Documents/Importe dDocuments/Tech_MAG_Strategy_Mapping_M arch07.pdf.

AUINGER, A. and FISCHER, M. (2008) 'Mining consumers ' opinions on the web', FH Science Day, (Linz, Österreich), pp. 410-419.

DEVIKA, M. D., SUNITHA, C. and GANESH, A. (2016) 'Sentiment Analysis: A Comparative Study on Different Approaches', Procedia Computer Science. The Author(s), 87, pp. 44-49. doi: 10.1016/j.procs.2016.05.124.

FANG, X. and ZHAN, J. (2015) 'Sentiment analysis using product review data', Journal of Big Data. Journal of Big Data, 2(1). doi: 10.1186/s40537015-0015-2.

HADDI, E., LIU, X. and SHI, Y. (2013) 'The role of text pre-processing in sentiment analysis', Procedia Computer Science. Elsevier B.V., 17, pp. 26-32. doi: 10.1016/j.procs.2013.05.005.

HAFNIKA, F. et al. (2016) 'Strategy Map Formulation For Designing Strategic Plan', Advance Business and Social Studies, 2(2), pp. 103-112. Available at: https://apiar.org.au/wpcontent/uploads/2016/08/8_APJABSS_ICABSS_ BRR732_BIZ-103-112.pdf.

HINTON, K. E. (2012) A Practical Guide to Strategic Planning in Higher Education, Society for College and University Planning. doi: 10.1073/pnas.1719902115.

HUTCHISON, C. S. (2018) 'Essential Insight Into Internet, Social Media, Mobile, and Ecommerce Use Around the World', In: the Ocean basins and margins: The Indian Ocean (Nairn, A.E.M. \& Stehli, F.G., Eds) Plenum Press, New York, 6, pp. 451-512.

HUTTO, C. J. and GILBERT, E. (2014) 'VADER: A Parsimonious Rule-based Model for Sentiment Analysis of Social Media Text', Proceedings of the Eighth International AAAI Conference on Weblogs and Social Media, pp. 216-225.

JANSSEN, D. et al. (2015) 'Sentiment Analysis of Social Media for Evaluating Universities', pp. 49-62.

LEE, M. and PARK, H. W. (2012) 'Exploring the web visibility of world-class universities', Scientometrics, 90(1), pp. 201-218. doi: 10.1007/s11192-011-0515-6.

LI, Q. et al. (2018) 'Web Media and Stock Markets : A Survey and Future Directions from a Big Data Perspective', IEEE Transactions on Knowledge and Data Engineering, 30(2), pp. 381-399. doi: 10.1109/TKDE.2017.2763144. 
LV, X. and EL-GOHARY, N. (2016) 'Text Analytics for Supporting Stakeholder Opinion Mining for Large-scale Highway Projects', Procedia Engineering. Elsevier B.V., 145, pp. 518-524. doi: 10.1016/j.proeng.2016.04.039.

MCCOY, C. G., NELSON, M. L. and WEIGLE, M. C. (2017) 'University Twitter Engagement: Using Twitter Followers to Rank Universities'. Available at: http://arxiv.org/abs/1708.05790.

MEDHAT, W., HASSAN, A. AND KORASHY, H. (2014) 'Sentiment analysis algorithms and applications: A survey', Ain Shams Engineering Journal. Faculty of Engineering, Ain Shams University, 5(4), pp. 1093-1113. doi: 10.1016/j.asej.2014.04.011.

MISHRA, N. (2012) 'Classification of Opinion Mining Techniques', 56(13), pp. 1-6.

‘Orange3 Text Mining Documentation’ (2018).

PANG, B. and LEE, L. (2006) 'Opinion Mining and Sentiment Analysis', Foundations and Trends ${ }^{\circledR}$ in InformatioPang, B., \& Lee, L. (2006). Opinion Mining and Sentiment Analysis. Foundations and Trends ${ }^{\circledR}$ in Information Retrieval, 1(2), 91-231. doi:10.1561/1500000001n Retrieval, 1(2), pp. 91-231. doi: 10.1561/1500000001.

PUTRANTI, N. D. and WINARKO, E. (2014) 'Analisis Sentimen Twitter untuk Teks Berbahasa Indonesia dengan Maximum Entropy dan Support Vector Machine', IJCCS (Indonesian Journal of Computing and Cybernetics Systems), 8(1), pp. 91-100. doi: 10.22146/ijccs.3499.

RITSON, N. (2011) The Levels and Formulation of Strategy, Strategic Management.

ROZI, I. F., PRAMONO, S. H. and DAHLAN, E. A. (2012) 'Implementasi Opinion Mining ( Analisis Sentimen ) untuk Ekstraksi Data Opini Publik pada Perguruan Tinggi', Electrical Power, Electronics, Communications, Controls, and Informatics Seminar (EECCIS), 6(1), pp. 37-43.

SCIENCE, C. and ENGINEERING, S. (2016) 'Algorithms for Opinion Mining and Sentiment Analysis: An Overview', 6(2), pp. 455-459.

SINGH, P. K. and HUSAIN, M. S. (2014) 'Methodological Study of Opinion Mining and Sentiment Analysis Techniques', 5(1), pp. 11-21. doi: 10.5121/ijsc.2014.5102.

SINGLA, Z., RANDHAWA, S. and JAIN, S. (2017) 'Sentiment Analysis of Customer Product Reviews Using Machine Learning'.

STEFANOVSKA, L. and SOKLEVSKI, T. (2014) 'Benefits of Using Balanced Scorecard in Strategic and Operational Planning, Universal
Journal of Management, 2(4), pp. 165-171. doi: $10.13189 /$.

STIEGLITZ, S. et al. (2014) 'Socialmedia analytics', Business and Information Systems Engineering, 6(2), pp. 89-96. doi: 10.1007/s12599-014-03157.

STIEGLITZ, S. et al. (2018) 'Social media analytics - Challenges in topic discovery, data collection, and data preparation', International Journal of Information Management. Elsevier, 39(October 2017), pp. 156-168. doi: 10.1016/j.ijinfomgt.2017.12.002.

TARTIR, S. and ABDUL-NABI, I. (2017) 'Semantic Sentiment Analysis in Arabic Social Media', Journal of King Saud University - Computer and Information Sciences. King Saud University, 29(2), pp. 229-233. doi: 10.1016/j.jksuci.2016.11.011.

THAMRIN, H. and PAMUNGKAS, E. W. (2017) 'A Rule Based SWOT Analysis Application: A Case Study for Indonesian Higher Education Institution', Procedia Computer Science. Elsevier B.V., 116(December), pp. 144-150. doi: 10.1016/j.procs.2017.10.056.

WEBOMETRIC (2018) The Ranking Web or Webometrics Methodology. Available at: http://www.webometrics.info/en/Methodology. 